\title{
The Determinants of Management Information Systems Effectiveness in Small- and Medium-Sized Enterprises
}

\author{
Quang Bon LE', Minh Dat NGUYEN², Van Can BUI ${ }^{3}$, Thi Mai Huong DANG ${ }^{4}$ \\ Received: May 21, 2020 Revised: May 31, 2020 Accepted: July 03, 2020
}

\begin{abstract}
This study develops a mediating model to explore the relationships between organizational characteristics, manager's knowledge, management commitment, user involvement, information quality, and management information system effectiveness in small- and medium-sized enterprises in Vietnam. Adapting scales from previous research, the authors designed questionnaires, which they distributed to respondents in Vietnamese small- and medium-sized enterprises. Also, by employing a meta-analytic path analysis throughout structural equation modelling (SEM) with sample of 356 respondents, authors indicate that organizational characteristics are directly related to management information systems effectiveness. Moreover, manager's knowledge, user involvement, and information quality show their important roles in the increase of management information system effectiveness, yet management commitment does not indicate a similar role in the growth of management information system effectiveness. Bootstrapping is utilized to discover the meditating role of information quality, illustrating that quality information mediates the linkages between user involvement, organizational characteristics, and management information systems. However, the mediating role of information quality in the relationship between management commitment, manager's knowledge, and management information systems is not significant. This study contributes to the management information system literature as well as to enhance MIS effects in small and medium-sized enterprises.
\end{abstract}

Keywords: Management Information Systems, Effectiveness, Information Quality, Small- and Medium-Sized Enterprises

JEL Classification Code: M10, M15, L86

\section{Introduction}

The development of information technology has changed many aspects of the world, including business management. This is best expressed in the method of providing and handling management data, which has made great progress compared

${ }^{1}$ First Author and Corresponding Author. Rector, University of Fire Prevention and Fighting, Vietnam [Postal Address: 243 Khuat Duy Tien Street, Nhan Chinh, Thanh Xuan, Hanoi, 100000, Vietnam] Email: lebon.gov@gmail.com

2Lecturer, Ho Chi Minh City University of Law, Vietnam.

Email: joe.nguyen1405@gmail.com

${ }^{3}$ Lecturer, Hanoi University of Business and Technology, Vietnam.

Email: buivancan03@gmail.com

${ }^{4} \mathrm{PhD}$ Student, Hanoi Metropolitan University, Vietnam.

Email: danghuong2055@gmail.com

(c) Copyright: The Author(s)

This is an Open Access article distributed under the terms of the Creative Commons Attribution Non-Commercial License (http://Creativecommons.org/licenses/by-nc/4.0/) which permits unrestricted noncommercial use, distribution, and reproduction in any medium, provided the original work is properly cited. to the process of manual management before. However, the management information systems (MIS) of enterprises in Vietnam, especially in small- and medium-sized enterprises (SMEs) remain limited. Therefore, it is necessary to build an effective management information system to provide accurate, complete and timely information to managers. Since then, the managers can make the right decisions, which contribute to improving firm performance and create the competitive advantages for businesses. Besides, the smalland medium-sized enterprises played a significant role in the Vietnamese economy with approximately $98 \%$ of the number of enterprises operating in Vietnam. But in practice, the management information systems of the small- and medium-sized enterprises still have restrictions when these systems only focus on financial management perspectives (Thanh et al., 2018).

The management information systems of small- and medium-sized enterprises in Vietnam were not fulfilling the role of providing useful information to managers in the decision-making process. Therefore, the identification and quantification of the factors affecting the management 
information systems effectiveness are essential to propose solutions that improve the quality of management decisions.

Worldwide, many aspects of the management information systems are interested in recent studies (Budiarto et al., 2015), such as enhancing strategic and tactical planning (Karim, 2011), teaching and learning evaluations (Strickley, 2004), and healthcare facilities (Potančok \& Voříšek, 2015). Also, research on the factors affecting the management information systems has also been carried out in recent years (Chiu et al., 2016; Ismail, 2009; Thong \& Yap, 1995; Hoang \& Ngoc, 2019; Nguyen et al., 2020) or information performance (Aujirpongpan \& Hareebin, 2020). In particular, the major factors that the authors are concerned with include the support of the consultants, the support of the suppliers, the participation of managers/owners, the top management commitment, management knowledge, organizational size, and level of accountant. The studies mentioned above make some contribution to theory as well as practical applications. However, following the contingency theory, the construction and design of the management information systems are affected by many different factors including many characteristics of the organization and external environment in which the organization is operating (Otley, 1980; Budiarto et al., 2015). Therefore, it is necessary to conduct research on the factors affecting the management information systems effectiveness in small- and medium-sized enterprises in Vietnam, which have different organizational characteristics and external environment compared to other businesses researched on over the world.

In Vietnam, most of the studies on the management information systems are related to organizing the management information systems for a firm, a group of firms or the group of administrative units. There is less research on the factors affecting the management information systems effectiveness in small- and medium-sized enterprises in Vietnam (Thanh et al., 2018). Therefore, it is still necessary to carry out an empirical study with sample collected from small- and medium-sized enterprises to find out what factors really affect the management information systems effectiveness of these types of enterprises in Vietnam. Factors such as organizational characteristics, manager's knowledge, management commitment, user involvement, and information quality should be explored regarding their roles in the increase of management information systems effectiveness. Thus, to address this research gap, this study tests the impact of organization's internal and external factors such as organizational characteristics, manager's knowledge, top management commitment, user involvement, and information quality on the effectiveness of management information systems in small- and medium-sized enterprises in Vietnam.
The remainder of this paper is divided into four sections as follows. After the introductory section, the authors present the literature review and hypothesis development in Section 2. Section 3 outlines the study methods, and Section 4 shows the empirical results. The paper ends with a discussion of the findings and conclusions.

\section{Literature Review}

\subsection{The Roles of Organizational Characteristics}

Size, organizational structure and business strategy are the three important organizational characteristics, which many researchers on the management information systems are particularly interested (Budiarto et al., 2015; Thong, 2001). In terms of organizational size, it is obvious that large-size companies usually have the potential of financial and human resources, so they more easily accept and use the management information systems effectively than smaller companies (Winston \& Dologite, 1999, Ismail \& King, 2007, Thong \& Yap, 1995), Moreover, Thong (1999) also suggested that the MIS projects are less successful in small businesses due to the limitation of resources and no formalize activity mechanism. Regarding the organizational structure, decentralization will make the managers bear more responsibility in planning activities, operation, and control. Therefore, they need more information to make decisions (Chenhall \& Morris, 1986).

Cheney and Dickson (1982) showed that the organizational characteristics have a positive impact on the management information systems because at this time the system has to work effectively to support managers in right and timely decision-making. With regard to business strategy, Premkumar and King (1994) revealed that the business strategy, including cost leadership and innovative differentiation, have a significant influence to the design of the management information systems. Thus, to design an efficient management information system, Tuanmat and Smith (2011) suggested that small- and medium-sized enterprises need to build an information technology strategy, which is suitable with the business strategy of the company. Besides, organizational characteristics are also seen as a determinant of increasing information quality (Mei-Liang \& Kuang-Jung, 2010). Therefore, the following research hypotheses are proposed:

H1: Organizational characteristics are positively related to information quality of small-and medium-sized enterprises in Vietnam.

H2: Organizational characteristics are positively related to management information systems effectiveness of smalland medium-sized enterprises in Vietnam. 


\subsection{The Roles of Managers' Knowledge}

Several studies show that the owners/managers are an important factor affecting the management information systems in the enterprises in a series of studies about the management information systems in small- and mediumsized enterprises (Ismail \& King, 2006, 2007). Also, Ismail (2009) suggests that the knowledge of managers/ owners has an impact on the management information systems effectiveness of Malaysian small- and mediumsized enterprises. Previously, one of the important factors affecting the application of the management information systems is the knowledge of system management (Thong, 1999). DeLone (1988) argued that the owner of a company is the key to the implementation of information technology. Managers' knowledge is extremely important for smalland medium-sized enterprises. The owners have more responsibility in the development of the management information systems (Delone et al., 1992). Therefore, the management information systems in businesses where owners have much knowledge and experience will be easier to deploy successfully. In Vietnam, the managers' knowledge also might have impacts on information quality and the effectiveness of the management information systems in small- and medium-sized enterprises. Therefore, the following research hypotheses are proposed:

H3. The managers' knowledge is positively related to information quality of small-and medium-sized enterprises in Vietnam.

H4. The managers' knowledge is positively related to management information systems effectiveness of small-and medium-sized enterprises in Vietnam.

\subsection{The Roles of Managerial Commitment}

The top management commitment mentions the involvement and the support of management for project implementation of the management information systems in the organization (Rapina, 2014). The importance of the involvement and support of management to the effectiveness of the MIS were recognized in studies (Thong \& Yep, 1995; Ismail \& King, 2007; Lee, 2014). Managers understand their business more than anyone, so their involvement can help management information systems project be suitable to the target and the strategy of the organization (Jarvenpaa \& Ives, 1991). Furthermore, the managers' commitment to participate in the process of deployment and implementation of management information systems will encourage users to develop a positive attitude of using management information systems and, thus, it also facilitates the process of implementation (Thong et al., 1996). The importance of the commitment of the managers/owners on the management information systems effectiveness and information quality should be examined (Carson \& Griffeth, 1990). For the small- and medium-sized enterprises in Vietnam, the top management commitment is essential to creating belief and motivation for all employees to build and use effectively information systems. Moreover, most of top managers are also owners in Vietnamese small- and medium-sized enterprises, so their commitment to management information systems projects is essential. Therefore, the following research hypotheses are proposed to investigate the roles of management commitment on information quality and management information systems in Vietnamese small- and medium-sized enterprises.

H5. The management commitment is positively related to information quality of small- and medium-sized enterprises in Vietnam.

H6. The management commitment is positively related to management information systems effectiveness of small-and medium-sized enterprises in Vietnam

\subsection{The Roles of User Involvement}

The user involvement is also an important factor affecting the successful implementation of management information systems. Iskandar (2015) explains that user involvement is the intervention of the user in the process from planning, developing to performing management information systems. These people use management information systems directly so they deeply understand the requirements of the systems that can meet the need of the business (Thong, 1999, 2001). Besides, during this process, they realize the shortcomings of management information systems. Therefore, their participation in the development process is necessary to perfect the system (Iskandar, 2015; Kim et al., 2020). In addition, it is required that this team must be knowledgeable about the process of organizing the activities of production and business of enterprises, capable of innovative, flexible, able of teamwork and collaboration with employees in other functional parts of businesses (Dezdar \& Ainin, 2011). Survey results from Vietnamese small- and medium-sized enterprises also can show similar situations. Therefore, user involvement can play an important role in the increase of information quality and management information effectiveness of small- and medium-sized enterprises in Vietnam. Thus, the following research hypotheses are proposed.

H7. The user involvement is positively related to information quality of small- and medium-sized enterprises in Vietnam. 
H8. The user involvement is positively related to management information systems effectiveness of small-and medium-sized enterprises in Vietnam.

\subsection{The Role of Information Quality}

The required information provided by the management information system play the crucial and consequent role in manager's decision-making. Information quality also has been discussed a great deal in the management information system literature (Vannirajan \& Manimaran, 2009). The information quality had greater interested researchers in management information systems effectiveness (Shagari et al., 2017). High information quality is examined as a key resource for companies that can be employed in enhancing their competitive advantage (Barney, 1991). The quality of a management information system is evaluated by the decisionmakers. However, Bailey and Pearson (1983) argue that the role of information quality in the increase of management information systems effectiveness is still adequately considered (Vannirajan \& Manimaran, 2009). Management information systems are considered a critical contribution to firms' performance. Also, information quality, which is measured by responsiveness, competence, reliability, assurance, empathy, and dependability, may be related to management information system effectiveness (Keltinger \& Lee, 1999). In the context of Vietnam, the following hypothesis is proposed to explore the relationship between information quality and the management information systems effectiveness.

H9. The information quality is positively related to management information systems effectiveness of small-and medium-sized enterprises in Vietnam.

\section{Research Methods}

\subsection{Sample}

This study employs quantitative research methods. On that basis, we propose the research hypotheses and outline the questionnaire. After the questionnaire is designed, the authors have emailed it to the employees and managers in small- and medium-sized enterprises in some provinces in Vietnam, including Hanoi, Ho Chi Minh, Da Nang, Bac Ninh, Hai Duong, Hung Yen, Vinh Phuc, Phu Tho, Lao Cai and Yen Bai. The subjects were selected to be surveyed because we believe they are the most knowledgeable about management information systems in their company. We approach the participants answering ourquestionnaire through convenience method. This means that we approached the suitable people that we know or through other social relationships. We sent 500 surveys and received back 428 respondents (approximately $85.6 \%$ ), out of which there are 356 valid returns. The invalid discarded responses included blank forms, insufficient answer sheets and surveys where only one level of questions were answered.

The results of descriptive statistics of demographic layouts shows that a fewer proportion of respondents are female, accounting for 45.8 , whereas $54.2 \%$ are male. In terms of age, just $20.8 \%$ respondents are over 50 years old, the high percentage of them are from 30 to 40 years old $(30.1 \%)$, followed by respondents who are under 30 years old $(25.2 \%)$ and from 40 to 50 years old $(23.9 \%)$. In addition, $59.4 \%$ respondents are married and only $40.6 \%$ of them are single (see Table 1).

Regarding the educational level, the large percentage of respondents had obtained a bachelor degree $(52.6 \%)$, followed by recipients of high school, Master, and $\mathrm{PhD}$

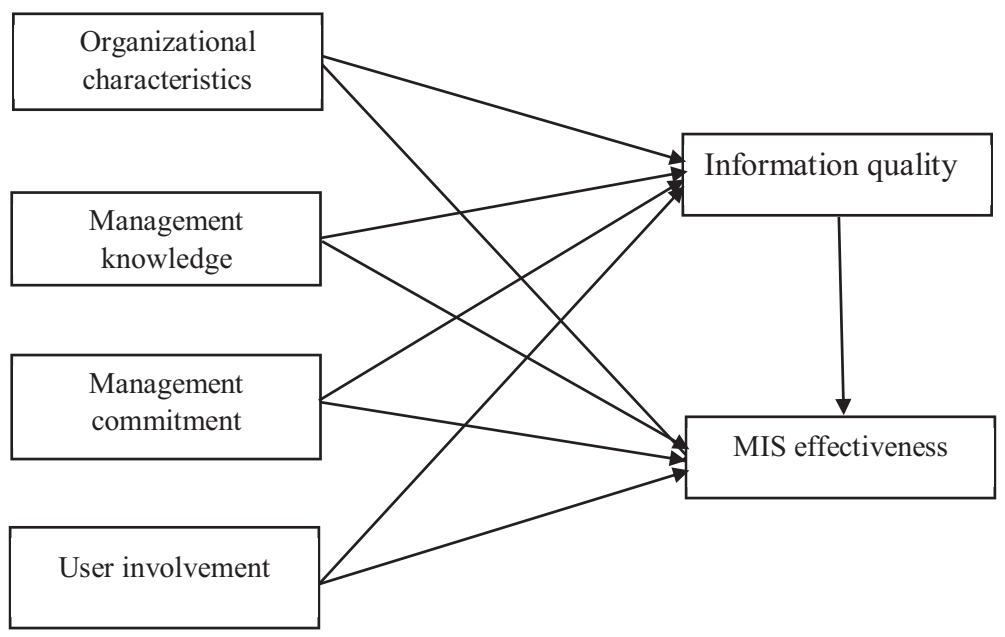

Figure 1: Conceptual framework 
Table 1: Descriptive statistics of sample demographics

\begin{tabular}{|l|l|c|c|}
\hline \multicolumn{2}{|c|}{ Demographic variables } & F & $\%$ \\
\hline \multirow{4}{*}{ 1. Gender } & Male & 193 & 54.2 \\
\cline { 2 - 4 } & Female & 163 & 45.8 \\
\hline & Under 30 years old & 90 & 25.2 \\
\cline { 2 - 4 } & From 30 to 40 years old & 107 & 30.1 \\
\cline { 2 - 4 } & From 40 to 50 years old & 85 & 23.9 \\
\cline { 2 - 4 } & Over 50 years old & 74 & 20.8 \\
\hline \multirow{3}{*}{ 3. Marital status } & Single & 145 & 40.6 \\
\hline & Married & 211 & 59.4 \\
\hline \multirow{5}{*}{ 4. Educational level } & High School & 56 & 15.8 \\
\cline { 2 - 4 } & Bachelor & 187 & 52.6 \\
\cline { 2 - 4 } & Master & 100 & 28.2 \\
\cline { 2 - 4 } & PhD & 12 & 3.4 \\
\hline \multirow{5}{*}{ 5. Working experience } & Under 4 years & 58 & 16.2 \\
\cline { 2 - 4 } & From 4 to 8 years & 104 & 29.3 \\
\cline { 2 - 4 } & From 8 to 12 years & 154 & 43.2 \\
\cline { 2 - 4 } & More than 12 years & 40 & 11.3 \\
\hline Note: N=356; F: Frequency; \%: Percent & & \\
\hline
\end{tabular}

degrees $(15.8 \%, 28.2 \%$ and $3.4 \%$, respectively). Moreover, $43.2 \%$ of respondents have 8 to 12 years of working experiences and only $16.2 \%$ of them had been working under 4 years.

\subsection{Scales}

The scale of variables in this study is borrowed from the previous studies. In particular, the scale of organizational characteristics is designed on the basis of borrowing and adjusting the scale conceived by Thong and Yap (1995), including three items: (1) characteristics of organization size; (2) characteristics of the organizational structure; and (3) characteristics of the business strategy. Using a fivepoint scale $(1=$ completely disagree; $5=$ completely agree $)$, respondents were asked to indicate their agreement levels about the above three items.

This study borrows the scale of manager's knowledge designed by Ismail and King (2007). Specifically, the scale of manager's knowledge is measured through five items: (1) knowledge of accounting; (2) basic computer skill; (3) knowledge of accounting software; (4) production management with the assistance of computers; and (5) search by the Internet. Using a five-point scale $(1=$ completely no knowledge; 5 = extensively knowledge), respondents were asked to indicate their knowledge levels about the above five items.
The scale of the top management commitment consists of three items: (1) support commitment; (2) involvement commitment; and (3) undertaking commitment. This scale is also modified from the scale in the study by Ismail and King (2007). Respondents were asked to indicate the commitment level of the above items on the Likert five-point scale from 1 (completely no commitment) to 5 (completely commitment).

To measure user involvement, the authors use the scale of Thong (2001). Using a five-point scale $(1=$ absolutely no involvement; 5 = highly involvement), respondents were asked to indicate their level of involvement in the following four areas: (1) user attendance at project meetings; (2) user involvement in information requirements analysis; (3) user involvement in reviewing consultant's recommendations; and (4) user involvement in information system decisionmaking.

Information quality scale is adapted from the study of Shagari et al. (2017). Using a five-point scale (1= strongly disagree, $5=$ strongly agree), respondents were asked to show their perception related to: (1) accurate information, (2) relevant information, and (3) updated information.

There are many different views on the effectiveness of management information systems. However, the majority of empirical studies previously measure the efficiency of management information systems through the satisfaction of the users regarding the quality of output information (Doll \& Torkzadeh, 1991; DeLone \& McLean, 1992). Therefore, 
in this study, we inherit the scale of Doll and Torkzadeh (1991). Accordingly, the output information of management information systems must ensure the important quality standards in view of the International Financial Reporting Standards (IFRS) and Vietnamese Accounting Standards (VAS) such as (1) Relevance, (2) Faithful representation, (3) Timeliness, (4) Understandability, (5) Ease of use, and (6) Information security. Respondents were asked to indicate the self-satisfaction level of the six above items on the Likert five-point scale from 1 (completely no satisfaction) to 5 (completely satisfaction).

\subsection{Analysis}

The authors perform a regression analysis to examine the contribution of factors (organization characteristics management knowledge, and user involvement) to information quality and management information systems effectiveness, and also explore the mediating roles of information quality in the linkages between organization characteristics, management knowledge, user involvement, and management information systems effectiveness. Structural equation modelling (SEM) should be employed to test the hypothesized relationships and the analysis process includes three main steps (Trang \& Doanh, 2019). Firstly, Cronbach's alpha and exploratory factor analysis (EFA) are used to examine the reliability of variables. Secondly, confirmatory factor analysis (CFA) was used to estimate the empirical validity of the research model and each measure. Finally, the structural equation modelling is then applied to estimate path coefficients for each proposed relationship in the conceptual framework. Besides, Doanh and Bernat (2019) suggest that bootstrapping methods recently become an effective tool to estimate the role of mediators. The statistical analysis is performed using SPSS 23.0 and AMOS 23.0 software.

\section{Results}

\subsection{The Variability of Scales}

According to the research results from Table 2, Cronbach's alpha coefficients of all variables ranges from 0.766 to 0.827 . Thus, all variables' Cronbach's alpha values are appropriate for testing reliability of scales. After estimating the reliability of scales by Cronbach's alpha, all 24 items are employed in the exploratory factor analysis (EFA). The results of testing the validity of measures (variables) by the exploratory factor analysis shows that $\mathrm{KMO}=0.920$, Sig. (Bartlett's Test $)=$ $0.000<0.005$, Initial Eigenvalues $=62.798>50 \%$. Thus, all scales are appropriate for confirmatory factor analysis at the next part. The final results of the exploratory factor analysis are also illustrated at Table 2.

\subsection{Confirmatory Factor Analysis}

In order to assess measurement validity, the authors performed the confirmatory factor analysis (CFA) throughout applying AMOS 23.0. The results generally illustrated a good level of fit for the measurement models. In particular, the results of CFA had revealed a reasonably good level of fit: $\chi^{2}(220)=451.518, \mathrm{p}=0.000 . \mathrm{CMIN} / \mathrm{df}=2.052<0.5$ (Kettinger \& Lee, 1995), CFI $=0.942, \mathrm{GFI}=0.905$, TLI $=$ $0.927>0.9$, RMSEA $=0.054$ (Bentler \& Bonnett, 1980). Finally, the convergent validity is identified at all scales. Table 3 presents the results of testing the discriminant validity between variables. The correlation of each couple of variables (r) and standard deviation (SE) are different to 1 (P-value $=0.000<0.005)$. Thus, the discriminant validity between variables are proved (see Table 3 ).

Table 4 presents the results of estimating the measurement validity by CFA. The results had represented standardized regression weights $(\lambda)$, composite reliability (CR) and average variance extracted (AVE) of all variables.

\subsection{Structural Equation Modelling Analysis}

The overall fit statistics of the model without the control variables illustrated an acceptable level of fit. So, the original model was used to test the hypothesized relationships (see Figure 2).

A total of nine hypotheses were tested in this study (see Table 5). Five of the nine hypothesized paths were statistically significant and four hypotheses were rejected in the direction predicted. Specially, organizational characteristics have strong effect on information quality $(\beta=0.696 ; p$-value $<0.001)$. However, the relationship between organizational characteristics and management information systems effectiveness is not significant ( $\mathrm{p}$-value $=0.750>0.05$ ). Manager's knowledge is directly related to management information systems effectiveness $(\beta=0.315$; p-value $<0.001$ ), but not information quality ( $\mathrm{p}$-value $=$ $0.116>0.05$ ). Surprisingly, management commitment is not directly involved in both management information systems effectiveness $(\mathrm{p}$-value $=0.530>0.05)$ and information quality ( -value $=0.535>0.05$ ), while user involvement is significantly related to both management information systems effectiveness $(\beta=0.294 ; p$-value $<0.001)$ and information quality $(\beta=0.133$; $\mathrm{p}$-value $<0.05)$. Finally, information quality plays an important role in the increase of management information systems effectiveness $(\beta=$ 0.608 ; $p$-value $<0.05$ ). Besides the direct effects of variables on management information systems effectiveness, this study also focuses on investigating the mediating role of information quality in the antecedents and management information systems effectiveness. Bootstrapping methods is employed to discover this role. 
Table 2: Cronbach's alpha and Exploratory Factor Analysis

\begin{tabular}{|c|c|c|c|c|c|c|c|}
\hline \multirow{2}{*}{\multicolumn{2}{|c|}{ Variables/items }} & \multicolumn{6}{|c|}{ Component } \\
\hline & & \multirow{2}{*}{$\begin{array}{c}1 \\
0.606\end{array}$} & \multirow[t]{2}{*}{2} & \multirow[t]{2}{*}{3} & \multirow{2}{*}{4} & \multirow{2}{*}{5} & \multirow{2}{*}{6} \\
\hline \multirow{3}{*}{$\begin{array}{l}\text { Organizational } \\
\text { characteristics (OC) }\end{array}$} & OC1 & & & & & & \\
\hline & $\mathrm{OC2}$ & 0.787 & & & & & \\
\hline & OC3 & 0.799 & & & & & \\
\hline \multirow{5}{*}{$\begin{array}{l}\text { Management } \\
\text { knowledge } \\
\text { (MK) }\end{array}$} & MK1 & & 0.634 & & & & \\
\hline & MK2 & & 0.752 & & & & \\
\hline & MK3 & & 0.842 & & & & \\
\hline & MK4 & & 0.583 & & & & \\
\hline & MK5 & & 0.527 & & & & \\
\hline \multirow{3}{*}{$\begin{array}{l}\text { Management } \\
\text { Commitment } \\
\text { (MC) }\end{array}$} & MC1 & & & 0.582 & & & \\
\hline & $\mathrm{MC2}$ & & & 0.794 & & & \\
\hline & MC3 & & & 0.733 & & & \\
\hline \multirow{3}{*}{$\begin{array}{l}\text { Information Quality } \\
\text { (IQ) }\end{array}$} & IQ1 & & & & 0.622 & & \\
\hline & IQ2 & & & & 0.566 & & \\
\hline & IQ3 & & & & 0.584 & & \\
\hline \multirow{6}{*}{$\begin{array}{l}\text { Management } \\
\text { Information systems } \\
\text { effectiveness } \\
\text { (MISe) }\end{array}$} & MISe1 & & & & & 0.539 & \\
\hline & MISe2 & & & & & 0.763 & \\
\hline & MISe3 & & & & & 0.805 & \\
\hline & MISe4 & & & & & 0.838 & \\
\hline & MISe5 & & & & & 0.856 & \\
\hline & MISe6 & & & & & 0.763 & \\
\hline \multirow[t]{4}{*}{ User Involvement (UI) } & UI1 & & & & & & 0.539 \\
\hline & UI2 & & & & & & 0.645 \\
\hline & UI3 & & & & & & 0.818 \\
\hline & UI4 & & & & & & 0.792 \\
\hline \multicolumn{2}{|l|}{ Cronbach's alpha $(\alpha)$} & 0.821 & 0.827 & 0.810 & 0.766 & 0.872 & 0.729 \\
\hline \multicolumn{2}{|l|}{ KMO } & \multicolumn{6}{|c|}{0.920} \\
\hline \multicolumn{2}{|l|}{ Sig. of Bartlett's test } & \multicolumn{6}{|c|}{0.000} \\
\hline \multicolumn{2}{|l|}{ Cumulative (\%) } & \multicolumn{6}{|c|}{62.798} \\
\hline \multicolumn{8}{|l|}{ Note: $\mathrm{N}=$} \\
\hline
\end{tabular}

Table 5 shows the indirect effects of organizational characteristics, manager's knowledge, management commitment, and user involvement on the effectiveness of management information systems via information quality. This results illustrate that the quality information mediates the linkages between user involvement (Bindirect UI-MISe $=0.179, \quad \mathrm{p}$-value $<0.05)$, organizational characteristics ( $\beta$ indirect OC-MISe $=0.140, \mathrm{p}$-value $<$ 0.05 ), and management information systems. However, the mediating role of information quality in the relationship between management commitment, manager's knowledge, and management information systems are not significant (p-value $>0.05)$.

\section{Conclusion}

This study not only uncovers the direct effects of organizational characteristics, manager's knowledge, management commitment, and user involvement on the effectiveness on management information system effectiveness, but it also focuses on exploring the mediating role of information quality in the relationship between these antecedents and management information system effects. The research shows that the information quality has the strongest effect on the effectiveness of management information systems, followed by managers' knowledge and user involvement. However, organizational 
Table 3: The results of testing the discriminant validity between variables

\begin{tabular}{|c|c|c|c|c|c|c|c|c|}
\hline \multicolumn{3}{|c|}{ Correlations } & $r$ & $1-r$ & $r^{2}$ & SE & CR & P-value \\
\hline MISe & $\leftrightarrow$ & $\mathrm{IQ}$ & 0.817 & 0.183 & 0.667 & 0.012 & 14.939 & 0.000 \\
\hline MISe & $\leftrightarrow$ & $O C$ & 0.299 & 0.701 & 0.089 & 0.020 & 34.581 & 0.000 \\
\hline MISe & $\leftrightarrow$ & $M C$ & 0.432 & 0.568 & 0.187 & 0.019 & 29.647 & 0.000 \\
\hline MISe & $\leftrightarrow$ & UI & 0.59 & 0.410 & 0.348 & 0.017 & 23.904 & 0.000 \\
\hline MISe & $\leftrightarrow$ & MK & 0.619 & 0.381 & 0.383 & 0.017 & 22.836 & 0.000 \\
\hline$I Q$ & $\leftrightarrow$ & OC & 0.414 & 0.586 & 0.171 & 0.019 & 30.305 & 0.000 \\
\hline IQ & $\leftrightarrow$ & MC & 0.414 & 0.586 & 0.171 & 0.019 & 30.305 & 0.000 \\
\hline IQ & $\leftrightarrow$ & $\mathrm{UI}$ & 0.571 & 0.429 & 0.326 & 0.017 & 24.599 & 0.000 \\
\hline$I Q$ & $\leftrightarrow$ & MK & 0.431 & 0.569 & 0.186 & 0.019 & 29.684 & 0.000 \\
\hline OC & $\leftrightarrow$ & $M C$ & 0.532 & 0.468 & 0.283 & 0.018 & 26.018 & 0.000 \\
\hline$O C$ & $\leftrightarrow$ & $\mathrm{UI}$ & 0.364 & 0.636 & 0.132 & 0.020 & 32.144 & 0.000 \\
\hline $\mathrm{OC}$ & $\leftrightarrow$ & MK & 0.22 & 0.780 & 0.048 & 0.021 & 37.640 & 0.000 \\
\hline$M C$ & $\leftrightarrow$ & $\mathrm{UI}$ & 0.44 & 0.560 & 0.194 & 0.019 & 29.356 & 0.000 \\
\hline MC & $\leftrightarrow$ & MK & 0.483 & 0.517 & 0.233 & 0.019 & 27.795 & 0.000 \\
\hline $\mathrm{UI}$ & $\leftrightarrow$ & MK & 0.751 & 0.249 & 0.564 & 0.014 & 17.752 & 0.000 \\
\hline
\end{tabular}

Table 4: The results of testing the measurement validity by confirmatory factor analysis (CFA)

\begin{tabular}{|l|c|c|c|c|}
\hline \multicolumn{1}{|c|}{ Scales } & $\boldsymbol{\lambda}$ & $\mathbf{C R}$ & AVE & Assessment \\
\hline MISe: Management Information Systems Effectiveness & 0.812 & 0.781 & 0.515 & reasonably good level \\
\hline OC: Organizational Characteristics & 0.758 & 0.681 & 0.612 & reasonably good level \\
\hline MK: Management Knowledge & 0.892 & 0.654 & 0.516 & reasonably good level \\
\hline MC: Management Commitment & 0.762 & 0.621 & 0.622 & reasonably good level \\
\hline IQ: Information Quality & 0.845 & 0.621 & 0.511 & reasonably good level \\
\hline UI: User involvement & 0.721 & 0.754 & 0.532 & reasonably good level \\
\hline Note: $N=356 ; \lambda$ Standardized Regression Weights; CR: Composite reliability; AVE: Average Variance Extracted.
\end{tabular}

Note: $\mathrm{N}=356$; $\lambda$ : Standardized Regression Weights; CR: Composite reliability; AVE: Average Variance Extracted.

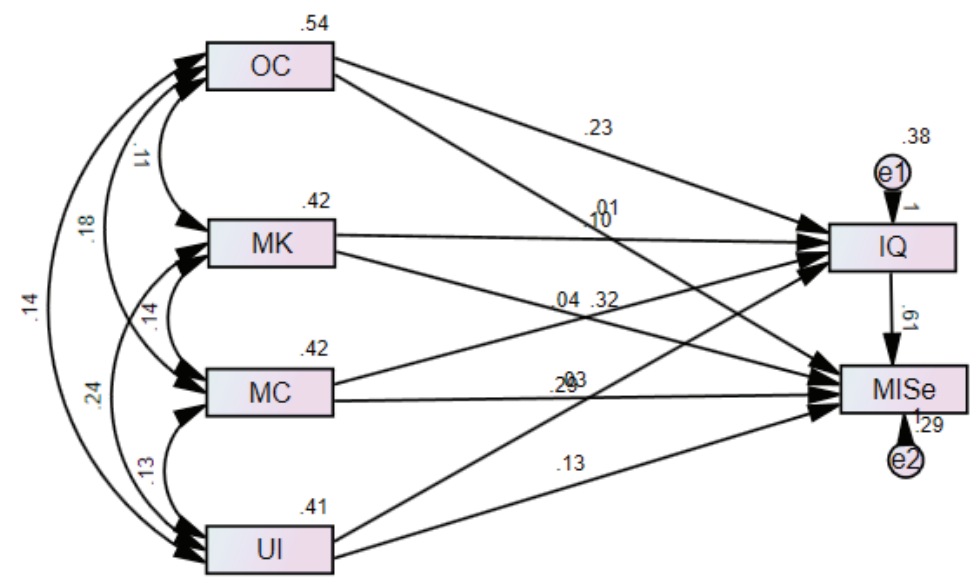

Figure 2: Structural equation modelling (unstandardized estimates) 
Table 5: The results of testing the research hypotheses

\begin{tabular}{|c|c|c|c|c|c|c|c|c|}
\hline \multicolumn{4}{|c|}{ Hypotheses } & Estimate & S.E & C.R & $\mathbf{P}$ & Conclusion \\
\hline $\mathrm{H} 1$ & OC & $\rightarrow$ & $\mathrm{IQ}$ & 0.231 & 0.049 & 4.746 & $* * *$ & Supported \\
\hline $\mathrm{H} 2$ & OC & $\rightarrow$ & MISe & 0.014 & 0.044 & 0.319 & 0.750 & Rejected \\
\hline $\mathrm{H} 3$ & MK & $\rightarrow$ & $\mathrm{IQ}$ & 0.099 & 0.063 & 1.572 & 0.116 & Rejected \\
\hline $\mathrm{H} 4$ & MK & $\rightarrow$ & MISe & 0.315 & 0.055 & 5.703 & $* * *$ & Supported \\
\hline $\mathrm{H} 5$ & MC & $\rightarrow$ & IQ & 0.038 & 0.056 & 0.670 & 0.503 & Rejected \\
\hline $\mathrm{H} 6$ & $\mathrm{MC}$ & $\rightarrow$ & MISe & 0.031 & 0.050 & 0.620 & 0.535 & Rejected \\
\hline $\mathrm{H} 7$ & UI & $\rightarrow$ & $\mathrm{IQ}$ & 0.294 & 0.064 & 4.600 & *** & Supported \\
\hline $\mathrm{H} 8$ & UI & $\rightarrow$ & MISe & 0.133 & 0.058 & 2.301 & 0.021 & Supported \\
\hline $\mathrm{H} 9$ & IQ & $\rightarrow$ & MISe & 0.608 & 0.047 & 13.023 & *** & Supported \\
\hline \multicolumn{9}{|c|}{ Indirect effects of variables } \\
\hline \multicolumn{4}{|c|}{ Variables } & UI & $\mathrm{OC}$ & $\mathrm{MC}$ & MK & $\mathrm{IQ}$ \\
\hline \multicolumn{4}{|c|}{ IQ } & .000 & .000 & .000 & .000 & .000 \\
\hline \multicolumn{4}{|l|}{ MISe } & $.179^{*}$ & $.140^{*}$ & .023 & .060 & .000 \\
\hline
\end{tabular}

characteristics and management commitment are not significantly related to management information systems effectiveness. Interestingly, this study reveals that, although organizational characteristics do not have direct effect, they have indirect influence on management information systems via information quality. In other worlds, information quality fully mediated the effect of organizational characteristics on management information systems effectiveness.

\section{References}

Aujirpongpan, S., \& Hareebin, Y. (2020). The effect of Strategic Intuition, Business Analytic, Networking Capabilities and Dynamic Strategy on Innovation Performance: The Empirical Study Thai Processed Food Exporters. Journal of Asian Finance, Economics and Business, 7(1), 259-268. https://doi. org/10.13106/jafeb.2020.vol7.no1.259

Bailey, J. E., \& Pearson, S. W. (1983). Development of a Tool for Measuring and Analyzing Computer User Satisfaction. Management Sciences, 29(5), 530-545.

Barney, J. (1991). Firm resources and sustained competitive advantage. Journal of Management, 17(1), 99-120. https://doi. org/10.1177/014920639101700108

Bentler,P.M., \& Bonett, D. G.(1980). Significance tests and goodness of fit in the analysis of covariance structures. Psychological Bulletin, 88(3), 588-606

Budiarto, D. S., Rahmawati, \& Prabowo, M. A. (2015). Accounting Information Systems Alignment and SMEs Performance: A Literature Review. International Journal of Management, Economics and Social Sciences, 4(2), 58-70.
Cheney, P., \& Dickson, G. (1982). Organizational Characteristics and Information Systems: An Exploratory Investigation. The Academy of Management Journal, 25(1), 170-184.

Chenhall, R. H., \& Morris, D. (1986). The impact of structure, environment, and interdependence on the perceived usefulness of management accounting systems. Accounting Review, 6(1), 16-35.

Chiu, P., Chao, I., Kao, C., Pu, Y., \& Huang, Y. (2016). Implementation and evaluation of mobile e-books in a cloud bookcase using the information system success model. Library Hi-Tech, 34(2), 207-223. https://doi.org/10.1108/LHT-122015-0113

Carson, K. D., \& Griffeth, R. W. (1990). Changing a management information system: managing resistance by attending to the rights and responsibilities of employees. Employee Responsibilities and Rights Journal, 3, 47-58.

DeLone, W. H. (1988). Determinants of success for computer usage in small business. MIS Quarterly, 12(1), 51-61.

DeLone, W. H., \& McLean, E. R. (1992). Information systems success: The quest for the dependent variable. Information Systems Research, 3(1), 60-95.

Doanh, D. C., Bernat, T. (2019). Factors related to the intention of starting a business: A study among students in Vietnam. Problemy Zarzadzania - Management Issues, 17(6), 133-157. https://doi.org/10.7172/1644-9584.86.8

Doll, W. J., \& Torkzadeh, G. (1991). The measurement of end-user computing satisfaction: theoretical and methodological issues. MIS Quarterly, 15(1), 5-10 
Iskandar, D. (2015). Analysis of Factors Affecting the Success of the Application of Accounting Information System. International Journal of Scientific \& Technology Research, 4(2), 155-162.

Ismail, N. A. (2009). Factors influencing AIS effectiveness among manufacturing SMEs: Evidence from Malaysia. The Electronic Journal of Information Systems in Developing Countries, 38(1), 1-19.

Ismail, N. A., \& King, M. (2006). The alignment of accounting and information systems in SMEs in Malaysia. Journal of Global Information Technology Management, 9(3), 24-42.

Ismail, N. A., \& King, M. (2007). Factors influencing the alignment of accounting information systems in small and medium sized Malaysian manufacturing firms. Journal of Information Systems and Small Business, 1(1-2), 1-20.

Jarvenpaa, S. L., \& Ives, B. (1991). Executive involvement and participation in the management of information technology. MIS Quarterly, 15(2), 205-227

Karim, A. J. (2011). The significance of management information systems for enhancing strategic and tactical planning. Journal of Information Systems and Technology Management, 8(2), 459-470.

Keltinger, W. J., \& Lee, C. C. (1999). Replication of Measures of Information Systems Research: The Case of IS SERVQUAL. Decision Sciences, 30(3), 893-899.

Kettinger, W. J., Lee, C. C., \& Lee, S. (1995). Global Measures of Information Services Quality: A Cross-National Study. Decision Sciences, 26(5), 569-588.

Kim, M., Choi, K. W., Chang, M., \& Lee, C. H. (2017). Overtourism in Jeju Island: the influence factors and mediating role of quality of life. Journal of Asian Finance, Economics and Business, 7(5), 145-154. https://doi.org/10.13106/jafeb.2020. vol7.no5.145

Hoang, C. C., \& Ngoc, B. H. (2019). The relationship between Innovation Capacity and Firm's Performance in Electronic Companies, Vietnam. Journal of Asian Finance, Economics and Business, 6(3), 295-304. https://doi.org/10.13106/jafeb.2019. vol6.no3.295

Mei-Liang, C. \& Kuang-Jung, C. (2010). The relations of organizational characteristics, customer-oriented behavior and information quality. African Journal of Business Management, 4(10), 2059-2074.

Lee, J.W. (2014). The impact of product distribution and information technology on Carbon Emissions and Economics Growth: Empirical Evidence in Korea. Journal of Asian Finance, Economics and Business, 1(3), 17-28. https://doi.org/10.13106/ jafeb.2014.vol1.no3.17.

Nguyen, T. M. H., Nguyen, N. T., \& Nguyen, H. T. (2020). Factors affecting voluntary information disclosure on Annual Reports: Listed Companies in Ho Chi Minh Stock Exchange. Journal of Asian Finance, Economics and Business, 7(3), 53-62. https:// doi.org/10.13106/jafeb.2020.vol7.no3.53

Otley, D. (1980). The contingency theory of management accounting: achievement and prognosis. Accounting, Organizations and Society, 5(4), 413-428.
Potančok, M., \& Voříšek, J. (2016). Specific factors influencing information system/information and communication technology sourcing strategies in healthcare facilities. Health Informatics Journal, 22(3), 536-547. https://doi. org/10.1177/1460458215571644

Premkumar, G., \& King, W. R. (1994). Organizational Characteristics and Information Systems Planning: An Empirical Study. Information Systems Research, 5(2), 75-109. doi:10.1287/isre.5.2.75

Rapina. (2014). Factors Influencing The Quality of Accounting Information System And Its Implications on The Quality of Accounting Information. Research Journal of Finance and Accounting, 5(2), 148-154.

Thanh, N.V., Yoon, H., \& Hwang, J. (2018). A study on the factors affect to technological adoption of e-Government information system interoperability in Vietnam. The International Technology Management Review, 7(1), 125-143.

Thong, J. Y. L. (1999). An integrated model of information systems adoption in small businesses. Journal of Management Information Systems, 15(4), 187-214.

Thong, J. Y. L. (2001). Resource constraints and information systems implementation in Singaporean small businesses. Omega, 29(2), 143-156.

Thong, J. Y. L., Yap, C.-S., \& Raman, K. (1996). Top management support, external expertise and information systems implementation in small businesses. Information Systems Research, 7(2), 248-267.

Thong, J. Y. L., \& Yap, C. S. (1995). CEO characteristics, organizational characteristics and information technology adoption in small businesses. Omega, 23(4), 429-442.

Trang, T. V., \& Doanh, D. C. (2019). The role of structural support in predicting entrepreneneurial intention. Management Science Letters, 9, 1783-1798.

Tuanmat, T. Z., \& Smith, M. (2011). The effects of changes in competition, technology and strategy on organizational performance in small and medium manufacturing companies. Asian Review of Accounting, 19(3), 208-220.

Shagari, S. L., Abdullah, A., \& Saat, R. (2017). Accounting information systems effectiveness: Evidence from the Nigerian Banking sector. Interdisciplinary Journal of Innovation, Knowledge and Management, 12, 309-335.

Strickley, A. (2004). Factors Affecting the Use of MIS as a Tool for Informing and Evaluating Teaching and Learning in Schools. Education and Information Technologies, 9, 47-66. https://doi.org/10.1023/B:EAIT.0000024261.33160.41

Vannirajan, T., \& Manimaran, S. (2009). Management Information Systems for Information quality in Commercial Banks: An Empirical Study. Asia Pacific Business Review, 5(2), 6174. https://doi.org/10.1177/09732470090050020

Winston, E. R., \& Dologite, D. G. (1999). Achieving IT infusion: A conceptual model for small businesses. Information Resources Management Journal, 12(1), 26-38. 